\title{
Diet effects on female reproduction in high growth (hg/hg) mice that are deficient in the Socs-2 gene
}

\author{
Pablo M. CORVA ${ }^{\mathrm{a}}$, Nicolás C. MUCCI ${ }^{\mathrm{a}}$, Kristin EvANS ${ }^{\mathrm{b}}$, \\ Juan F. MEDRANO ${ }^{\mathrm{b} *}$ \\ a Department of Animal Science, College of Agriculture, University of Mar del Plata CC 276, \\ 7620 Balcarce, Argentina \\ b Department of Animal Science, University of California, Davis, One Shields Ave, Davis, \\ CA 95616-8521, USA
}

(Received 27 March 2003; accepted 17 December 2003)

\begin{abstract}
The detrimental effect of larger body size on reproductive performance has been well documented in mouse models of overgrowth, such as Growth Hormone (GH) transgenics. This study describes the reproductive performance of the High Growth (HG) mouse model of overgrowth. The HG mouse model exhibits overgrowth due to a partially recessive autosomal mutation that increases growth rate and mature body size. The HG phenotype results from the lack of expression of Socs-2, which negatively regulates GH signaling. C57BL/6J (C57) and congenic C57BL/6J-hg/hg (HG) female mice were fed four diets differing in protein and energy content, starting at 8 weeks of age. A complete reproductive cycle from mating to weaning was evaluated. HG mice were $40 \%$ larger than C57 and had a higher feed intake throughout the experiment. Significant genotype $\times$ diet interactions were detected for growth, body composition and reproductive traits. HG females showed poor reproductive performance compared to controls as demonstrated by their lower fertility during mating, which was not overcome by changes in the diet. No differences were detected in litter size, but HG animals exhibited a longer gestation length and heavier pup weaning weights compared to controls. Reproductive impairment in HG seems to be the consequence of the lack of Socs-2 independent of the effects of increased body size on reproduction.
\end{abstract}

genetics / overgrowth / genotype-nutrition interaction / reproduction

\section{INTRODUCTION}

In both wild and domestic mammals, good reproductive performance is an indicator of fitness to the environment [1]. When the equilibrium between nutritional resources and requirements is altered, one of the first manifestations is reproductive impairment. A key factor defining the equilibrium between nutritional resources and requirements is body size. Selection experiments in mice revealed that higher body weight is correlated with an increased ovulation rate; however, there is a trend to a negative association with fertility and reproductive lifespan [2]. Studies with transgenic mice over expressing growth hormone $(\mathrm{GH})$ also suggest a detrimental influence of increased body size on reproductive

\footnotetext{
* Corresponding author: jfmedrano@ucdavis.edu
} 
performance. This effect is attributed to energy deficits due to changes in nutritional partitioning in the larger, fast-growing animals $[3,4]$. In fact, reproductive failure in $\mathrm{GH}$ transgenics can be partially overcome by feeding high-energy diets [5]. This positive effect of the diet is mainly due to a reduction in post-implantation embryonic loss rate [5].

The high growth (HG) mouse model of overgrowth [6] has been characterized and is due to a partially recessive mutation $(h g)$ that enhances post-weaning weight gain and adult body size by $30-50 \%$. The $h g$ mutation is due to a $460 \mathrm{~kb}$ deletion in mouse chromosome 10 that includes three known genes, Suppressor of cytokine signaling 2 (Socs-2), RIP-associated ICDH-1/ CED-3-homologous protein with a death domain (Raidd/Cradd), and Plexin C1 [7]. The HG phenotype results from the lack of expression of Socs-2 [8], which negatively regulates GH signal transduction. This has been confirmed by the similarity of the HG phenotype to the phenotype resulting from a Socs-2 knockout mouse [9]. Homozygous $h g / h g$ mice have a distinctive hormonal profile, with very high levels of IGF-1, but very low levels of $\mathrm{GH}$ [10]. In addition to the effects of $h g$ on growth and body size, $h g / h g$ females also suffer from poor reproductive performance. Cargill et al. [11] showed that $h g / h g$ females demonstrate an increased incidence of recycling, increased intervals from mating to conception, reduced litter sizes and poor maternal behavior as compared to C57BL6/J controls. Given the improvement of reproductive performance observed in $\mathrm{GH}$ transgenics fed different diets and considering the size similarities that exist between the phenotypes of both models, we evaluated the reproductive response of $h g / h g$ mice resulting from changes in the diet. In an earlier report, we described important genotype $\times$ diet interactions involving $h g / h g$ male mice for growth and body composition [12]. In the present experiment we evaluated the reproductive performance of $h g / h g$ female mice under a nutritional protocol similar to the one previously used to study growth [12], with the objective of determining the effects of a diet intervention on reproductive interactions resulting from the lack of Socs-2.

\section{MATERIALS AND METHODS}

\subsection{Animals and Diets}

The $h g$ locus has been introgressed into the C57BL/6J (C57) background by nine backcrosses to create the congenic line, C57BL/6J-hg/hg (HG). In the present experiment, animals from the twenty-third generation of inbreeding were used. Fifteen female mice from each line, C57 control and HG congenic were allocated to one of four diets (Tab. I). Three of the diets were used in a previous experiment in order to evaluate the existence of genotype $x$ diet interactions for growth traits with the same congenic lines [12]. These diets (Dyets Inc., Bethlehem, PA) were formulated to vary the quantity of crude protein and fat using

Table I. Composition of the experimental diets.

\begin{tabular}{lcccc}
\hline & \multicolumn{3}{c}{ Diet $^{1}$} \\
\cline { 2 - 5 } Component & $\mathrm{C}$ & HE & HEP & 5015 \\
\hline Protein (\%) & 22.5 & 22.5 & 26.1 & 17.5 \\
Carbohydrates (\%) & 56.8 & 56.8 & 53.2 & 53.5 \\
Fat (\%) & 4.0 & 10.0 & 10.0 & 11.0 \\
Energy (Mcal.g ${ }^{-1}$ ) & 3.4 & 3.9 & 3.9 & 3.8 \\
\hline
\end{tabular}

${ }^{1}$ Diets C, HE and HEP were formulated by Dyets Inc. (Bethlehem, PA). Rodent chow No. 5015 is a product of Purina (St Louis, MO). 
the same ingredients. Briefly, the control diet (C) had $22.5 \%$ crude protein and $3.4 \mathrm{Kcal} \cdot \mathrm{g}^{-1}$ ( $11 \%$ of the energy from fat). Fat content was changed in a high-energy diet (HE) to increase the energy level to $3.9 \mathrm{Kcal} \cdot \mathrm{g}^{-1}$ (23\% of the energy from fat) while maintaining a constant protein concentration. The third diet (HEP) contained the same fat and energy content as the HE diet, but had a higher protein content (26.1\%) to maintain the same protein/energy ratio as in diet $\mathrm{C}$. Breeding females in our mouse colony are normally fed a 50:50 mix of Purina ( $\mathrm{St}$ Louis, MO) rodent chows no. 5008 (23.5\% protein, $6.5 \%$ fat) and 5015 (17.5\% protein, $11 \%$ fat). Purina 5015 has an energy level of $3.8 \mathrm{Kcal} \cdot \mathrm{g}^{-1}$ ( $26 \%$ from fat) and lower protein content than the diets mentioned above. Therefore, for the sake of comparison, Purina 5015 was included in the experiment as the fourth diet. Diet pellets were of similar size and hardness. Mice were housed in plexiglas cages bedded with wood shavings under controlled conditions of temperature $\left(21{ }^{\circ} \mathrm{C} \pm 2{ }^{\circ} \mathrm{C}\right)$, humidity $(40-70 \%)$ and lighting (14L:10D, lights on at 6 A.M.), and managed according to the guidelines of the American Association for Accreditation of Laboratory Animal Care (AAALAC).

\subsection{Experimental procedures}

Eight-week old virgin females were placed in harem cages ( 3 females each) and randomly assigned to one of the diets. Experimental diets were provided to all cages 7 days before mating, through pregnancy and weaning. Two males of the same age and line were assigned to each group of females and kept in separate cages until mating. These males were fed the same diet as the females. When mice were 9-wk old, one male was introduced in the females' cage. The females were checked daily for the presence of mating plugs. One or two days before the expected pupping date, pregnant females were removed from the mating cages and housed individually. Live pups were counted at birth and 3 weeks later at weaning. Females that did not conceive after detection of three mating plugs and pregnant females that lost their litters after pupping were removed from the experiment.

Female mice were weighed to the nearest $0.1 \mathrm{~g}$ at 8 and 10 weeks of age and at the end of lactation. Pups were weighed at weaning (3 weeks of age). At the end of lactation, the females were sacrificed by cervical dislocation under isoflurane (Aerrane, Ohmeda, Liberty Corner NJ) anesthesia. Liver, kidneys, heart, carcass and two intra-abdominal fat pads (gonadal and retroperitoneal) were individually weighed. The weight of the gonadal fat pad is considered representative of the whole level of fat stores in the animal [13].

The feed intake of each cage with female mice was estimated as the difference between the weight of offered feed and the remnants at seven-day intervals without considering spillage. Feed intake was measured during the week previous to mating, first week of mating and the three weeks of lactation. Feed intake was not measured beyond the first week of mating because females were in different stages of gestation and left the cage on different dates. Water was offered ad libitum throughout the experiment.

\subsection{Statistical analyses}

The results corresponding to live weights, feed intake, litter size and body composition were analyzed with linear models that included the fixed effects of line, diet and 2-way interactions, using the GLM procedure of SAS [14]. For the analyses of organ and fat weights, the number of pups weaned was included as a covariate. The sex of the pup was included in the model for the analysis of weaning weight. Linear contrasts were designed in order to test for differences among diets within each line. Intervals between mating and conception showed a very skewed distribution that resembled the Poisson distribution. Therefore, data for this trait was analyzed with the same model described above but using the Genmod procedure of SAS. 
Table II. Body weight and feed intake of High Growth (HG) and Control (C57) mice fed four different diets, and probabilities of the effects of Diet, Line and Diet within Lines.

\begin{tabular}{|c|c|c|c|c|c|c|c|c|c|c|}
\hline \multirow[b]{2}{*}{ Line } & \multirow[b]{2}{*}{ Diet } & \multicolumn{4}{|c|}{ Body weight (g) } & \multicolumn{5}{|c|}{ Feed intake } \\
\hline & & $n$ & $\begin{array}{l}\text { 8-wk } \\
\text { females }\end{array}$ & $n$ & $\begin{array}{l}10-w k \\
\text { females }\end{array}$ & $n$ & $\begin{array}{l}\text { Females }^{1} \\
\left(\mathrm{~g} \cdot \mathrm{day}^{-1}\right)\end{array}$ & $\begin{array}{c}\text { Females }+ \\
\operatorname{Male}^{2}\left(\mathrm{~g} \cdot \text { day }^{-1}\right)\end{array}$ & $n$ & $\begin{array}{c}\text { Lactation }^{3} \\
\left(\mathrm{~g} \cdot 3 \text { weeks }^{-1}\right)\end{array}$ \\
\hline \multirow[t]{4}{*}{$\begin{array}{l}\mathrm{C} 57 \\
\end{array}$} & 5015 & 15 & $20.9(1.2)$ & 15 & $23.9(2.1)^{b}$ & 5 & $10.8(0.9)^{\mathrm{b}}$ & $13.8(1.2)^{\mathrm{c}}$ & 11 & $265.0(8.9)^{\mathrm{b}}$ \\
\hline & $\mathrm{C}$ & 15 & $20.7(0.9)$ & 15 & $22.2(1.4)^{\mathrm{a}}$ & 5 & $8.7(0.4)^{\mathrm{a}}$ & $11.5(0.6)^{b}$ & 9 & $210.0(10.2)^{\mathrm{a}}$ \\
\hline & HE & 15 & $21.5(1.1)$ & 15 & $22.5(1.4)^{\mathrm{a}}$ & 5 & $7.7(0.2)^{\mathrm{a}}$ & $10.6(0.6)^{\mathrm{ab}}$ & 9 & $184.8(10.0)^{\mathrm{a}}$ \\
\hline & HEP & 15 & $21.9(1.8)$ & 15 & $22.2(2.0)^{\mathrm{a}}$ & 5 & $8.0(0.9)^{\mathrm{a}}$ & $8.9(2.1)^{\mathrm{a}}$ & 11 & $196.8(9.0)^{\mathrm{a}}$ \\
\hline \multirow[t]{4}{*}{$\mathrm{HG}$} & 5015 & 15 & $28.9(2.6)$ & 15 & $31.6(3.2)^{\mathrm{a}}$ & 5 & $15.3(1.7)^{\mathrm{b}}$ & $19.1(3.3)^{\mathrm{c}}$ & 10 & $389.5(9.5)^{\mathrm{b}}$ \\
\hline & $\mathrm{C}$ & 15 & $29.4(2.0)$ & 15 & $29.8(1.9)^{\mathrm{a}}$ & 5 & $11.5(0.5)^{\mathrm{a}}$ & $15.8(1.4)^{\mathrm{b}}$ & 10 & $254.7(9.5)^{\mathrm{a}}$ \\
\hline & $\mathrm{HE}$ & 15 & $29.8(2.4)$ & 15 & $30.7(2.4)^{\mathrm{a}}$ & 5 & $10.5(0.5)^{\mathrm{a}}$ & $13.7(1.1)^{\mathrm{a}}$ & 9 & $255.5(9.9)^{\mathrm{a}}$ \\
\hline & HEP & 15 & $30.7(3.7)$ & 15 & $31.0(2.0)^{\mathrm{a}}$ & 5 & $10.4(0.6)^{\mathrm{a}}$ & $13.7(0.2)^{\mathrm{a}}$ & 10 & $246.3(9.4)^{\mathrm{a}}$ \\
\hline \multicolumn{11}{|c|}{ Probabilities } \\
\hline \multicolumn{2}{|l|}{ Diet } & & NS & & $*$ & & $* * *$ & $* * *$ & & $* * *$ \\
\hline \multicolumn{2}{|l|}{ Line } & & $* * *$ & & $* * *$ & & $* * *$ & $* * *$ & & $* * *$ \\
\hline \multicolumn{2}{|c|}{ Diet within C57 } & & NS & & $*$ & & $* * *$ & $* * *$ & & $* * *$ \\
\hline \multicolumn{2}{|c|}{ Diet within HG } & & NS & & NS & & $* * *$ & $* * *$ & & $* * *$ \\
\hline
\end{tabular}

Feed intake was measured on a per cage basis: ${ }^{1}$ one week previous to mating $\left(3\right.$ females cage $\left.{ }^{-1}\right),{ }^{2}$ first week of mating ( 3 females +1 male-cage $\left.{ }^{-1}\right),{ }^{3}$ three-weeks of lactation $\left(1\right.$ female $\cdot$ cage $\left.^{-1}\right)$. Means within line sharing a common superscript $(\mathrm{a}, \mathrm{b}, \mathrm{c})$ are not significantly different $(P>0.05)$. Means of line within diet differed significantly for all traits $(P<0.05)$. Standard errors are shown in parenthesis next to each mean value. Threshold values for probabilities are NS: $P>0.05, * P<0.05$, $* * P<0.01, * * * P<0.001$.

\section{RESULTS}

\subsection{Live weight and feed intake}

At the beginning of the experiment, $\mathrm{HG}$ females were on average $40 \%$ heavier than C57 females (Tab. II). There were no differences in live weight within lines at this stage. At 10 weeks of age all mice had gained weight and the weight between lines within diet was significantly different for all diet treatments. In general, weight gain tended to be the highest for diet 5015 and the lowest for diet C. At the end of lactation, only the larger HG mice showed significant differences in body weight among diets. HG females fed diet 5015 were significantly heavier while those on diet $\mathrm{C}$ were the smallest (Tab. V).

In agreement with the difference in body size, HG mice had a higher feed intake than C57 mice throughout the experiment (Tab. II).
For both the HG and C57 lines, the highest feed intake was observed for diet 5015 at every stage of the experiment (prior to mating, mating and lactation). There were no differences in intake among the other three diets. When a male was introduced in each cage, the intake of diet 5015 remained significantly higher than the other three diets. During lactation, marked differences in intake were detected, again between 5015 and the rest of the diets. In C57 females at this stage the intake of diet 5015 was $26 \%$, $43 \%$ and $34 \%$ higher than the intake of diets $\mathrm{C}, \mathrm{HE}$ and HEP, respectively. For the HG females, the corresponding values were $52 \%, 52 \%$ and $58 \%$, respectively.

The examination of feed intake results in Table II suggests that the ad libitum consumptions of the different feeds resulted in relatively equal consumption of protein, with a trend to a higher protein consumption 
Table III. Number of females that became pregnant and reared a litter during the experiment and interval between mating and conception for High Growth (HG) and Control (C57) mice fed four different diets (Purina 5015; C, control; HE, high-energy; HEP, high energy high protein).

\begin{tabular}{lcccc}
\hline Line & Diet & $\begin{array}{c}\text { No. (\%) pregnant } \\
\text { females }\end{array}$ & $\begin{array}{c}\text { No. (\%) nursing } \\
\text { females }\end{array}$ & $\begin{array}{c}\text { Interval from mating to } \\
\text { conception (days) }^{1}\end{array}$ \\
\hline C57 & 5015 & $15(100.0 \%)$ & $11(73.3 \%)$ & $3.7(1.14)^{\mathrm{a}}$ \\
& $\mathrm{C}$ & $12(80.0 \%)$ & $9(60.0 \%)$ & $5.8(1.12)^{\mathrm{b}}$ \\
& $\mathrm{HE}$ & $13(86.6 \%)$ & $9(60.0 \%)$ & $7.3(1.26)^{\mathrm{b}}$ \\
$\mathrm{HG}$ & $\mathrm{HEP}$ & $12(80.0 \%)$ & $11(73.3 \%)$ & $10.8(1.09)^{\mathrm{c}}$ \\
& 5015 & $11(73.3 \%)$ & $9(60.0 \%)$ & $10.9(1.09)^{\mathrm{b}}$ \\
& $\mathrm{C}$ & $12(80.0 \%)$ & $10(66.7 \%)$ & $6.5(1.12)^{\mathrm{a}}$ \\
& $\mathrm{HE}$ & $12(80.0 \%)$ & $9(60.0 \%)$ & $13.3(1.08)^{\mathrm{c}}$ \\
Probabilities & $\mathrm{HEP}$ & $13(86.6 \%)$ & $10(66.7 \%)$ & $10.5(1.09)^{\mathrm{b}}$ \\
Diet & & & & \\
Line & & N/A & N/A & $* * *$ \\
Diet within C57 & N/A & N/A & $* * *$ \\
Diet within HG & N/A & N/A & $* * *$ \\
\hline
\end{tabular}

Diet means within line sharing a common superscript $\left({ }^{a, b, c}\right)$ are not significantly different. Line means within diet were significantly different $(P<0.05)$ in diets 5015 and HE.

${ }^{1}$ Standard error is shown in parenthesis next to each mean value. Threshold values for probabilities are NS: $P>0.05, * P<0.05, * * P<0.01, * * * P<0.001$.

in diet HEP for both lines in all stages. Energy intake, however, was highly different among diets, especially when diet 5015 was compared to the other three diets.

\subsection{Reproductive performance}

From the fifteen C57 females originally allocated to each diet, those on diet 5015 all became pregnant (Tab. III). The number of C57 females that did not conceive were three on diet $\mathrm{C}$, two on $\mathrm{HE}$ and three on HEP. Among the HG females, the number of those that did not conceive were four in 5015, three on C, three on HE and two on HEP. A difference in pregnancy rate was manifested between C57 and HG (15 and 11 pregnant females, respectively) only when mice were fed diet 5015. Across diets, eight C57 and twelve HG females never became pregnant and were removed from the experiment.

The females that became pregnant showed marked differences in the interval between mating and conception (Tab. III). This became one of the most relevant features of reproductive performance of $\mathrm{HG}$ females compared to C57. In C57, the ranking of diets with respect to the interval between mating and conception was $5015<\mathrm{C}=\mathrm{HE}<$ HEP. Interestingly, this ranking correlates with protein content of the diets: 5015 $(17.5 \%)<\mathrm{C}=\operatorname{HE}(22.5 \%)<\operatorname{HEP}(26.1 \%)$. Among HG females, no clear trend was detected between fertility and diet components. Lines did not differ in the interval from mating to conception in diets $\mathrm{C}$ and HEP. Surprisingly, the best reproductive performance of $\mathrm{HG}$ females corresponded to $\operatorname{diet} \mathrm{C}$, the one with the lowest energy and protein content. However, reproductive performance of $\mathrm{HG}$ females on any of the diets did not approach the performance of C57 females on diet 5015, the group with the shortest interval from mating to conception (3.67 \pm 1.14 days).

In agreement with the previous results reported by Cargill et al.[11], gestation length was greater for $\mathrm{HG}$ than $\mathrm{C} 57$ females $(20.0 \pm$ 0.17 days vs. $18.9 \pm 0.18$ days, respectively, $P<0.0001)$. Among those females that became pregnant, some of them lost their 
Table IV. Number of pups born and weaned and pup weaning weight for High Growth (HG) and Control (C57) mice fed four different diets, and probabilities of the effects of Diet, Line and Diet within Lines.

\begin{tabular}{lccccccc}
\hline Line & Diet & $n$ & No. pups born & $n$ & No. pups weaned & $n$ & Weaning weight (g) \\
\hline C57 & 5015 & 14 & $8.1(0.56)$ & 11 & $7.0(0.52)$ & 77 & $9.5(0.18)^{\mathrm{c}}$ \\
& C & 11 & $8.4(0.63)$ & 9 & $8.5(0.57)^{1}$ & 76 & $7.3(0.18)^{\mathrm{a}, 2}$ \\
& HE & 12 & $7.1(0.60)$ & 9 & $6.8(0.58)$ & 61 & $8.1(0.20)^{\mathrm{b}}$ \\
HG & HEP & 11 & $8.4(0.63)$ & 11 & $7.3(0.52)$ & 80 & $8.0(0.18)^{\mathrm{b}}$ \\
& 5015 & 10 & $8.7(0.66)$ & 9 & $7.8(0.55)$ & 72 & $11.6(0.18)^{\mathrm{c}}$ \\
& $\mathrm{C}$ & 12 & $8.5(0.60)$ & 10 & $6.9(0.55)^{1}$ & 69 & $7.5(0.19)^{\mathrm{a}, 2}$ \\
& HE & 11 & $7.9(0.63)$ & 9 & $7.4(0.58)$ & 67 & $9.9(0.19)^{\mathrm{b}}$ \\
\multicolumn{1}{l}{ Probabilities } & HEP & 12 & $8.1(0.60)$ & 10 & $7.0(0.55)$ & 70 & $9.7(0.19)^{\mathrm{b}}$ \\
Diet & & & & & & $* * *$ \\
Line & & NS & & $*$ & & $* * *$ \\
Diet within C57 & & NS & NS & NS & & $* * *$ \\
Diet within HG & & NS & NS & & $* * *$ \\
\hline
\end{tabular}

Diet weaning weight means within line sharing a common superscript $(\mathrm{a}, \mathrm{b}, \mathrm{c})$ are not significantly different $(P>0.05)$. Standard error of the mean is shown in parenthesis next to each mean value. Threshold values for probabilities are NS: $P>0.05, * P<0.05$, ** $P<0.01$, *** $P<0.001$.

${ }^{1}$ Line means within diet of number of pups weaned were significantly different only in $\operatorname{diet} \mathrm{C}(P<0.05)$.

${ }^{2}$ Line means within diet of average weaning weight were significantly different $(P<0.05)$ in all diets except diet $\mathrm{C}$.

litters at or shortly after pupping. This group included four C57 females on diet 5015 , three on $\mathrm{C}$, four on $\mathrm{HE}$ and one on HEP. Among the HG females, the corresponding values were two on 5015 , two on $\mathrm{C}$, three on HE and three on HEP (Tab. III).

There were no significant differences in the number of pups born, either between lines or diets (Tab. IV). Only when HG females were fed diet $\mathrm{C}$ did females wean significantly fewer pups than C57 (6.9 vs. 8.5).

HG females weaned heavier pups than C57 in all diets except diet C (Tab. IV). In fact, this diet was associated with the lowest weaning weights in both lines. For weaning weight, diet 5015 showed superiority over the other three diets. In turn, pups from the HE and HEP groups were heavier than those from $\mathrm{C}$ in both lines.

\subsection{Body composition}

Variation in body weight among HG females at slaughter was partially explained by differences in weight of some organs (Tab. V). Differences in carcass weight paralleled those of body weight. Aside from differences in fat stores that remained in the carcass, the lighter carcass weight of $\mathrm{HG}$ females on diet $\mathrm{C}$ suggested that growth was impaired in this group although this effect was not seen in the C57 line. HG females on diet $\mathrm{C}$ also had lower heart weights. The weight of the liver was higher for both C57 and HG females on diet 5015 . Interestingly, heavier kidneys were detected only in C57 females that were fed diet HEP, the diet with the highest protein content. When organ weight expressed as a percentage of body weight was compared between C57 and HG mice across diets, significant differences were detected for the carcass $(57.7 \pm 0.39 \%$ vs. $60.2 \pm 0.41 \%$, respectively), heart $(0.64 \pm 0.014 \%$ vs. $0.60 \pm$ $0.014 \%$, respectively) and kidneys (1.38 \pm $0.017 \%$ vs. $1.22 \pm 0.017 \%$, respectively).

Differences in size of fat depots also contributed to a variation in body weight. Diets 
Table V. Size of body components of High Growth (HG) and Control (C57) female mice fed four different diets, and probabilities of the effects of Diet, Line and Diet within Lines.

\begin{tabular}{|c|c|c|c|c|c|c|c|c|c|}
\hline Line & Diet & $n$ & Body (g) & Carcass (g) & Liver $(\mathrm{g})$ & Heart $(\mathrm{g})$ & Kidneys (g) & Gonadal fat $(\mathrm{g})$ & Retroperitoneal fat (g) \\
\hline \multirow[t]{4}{*}{$\mathrm{C} 57$} & 5015 & 11 & $27.9(0.7)^{\mathrm{a}}$ & $16.1(0.4)^{\mathrm{a}}$ & $1.66(0.09)^{\mathrm{a}}$ & $0.174(0.008)^{\mathrm{a}}$ & $0.367(0.012)^{\mathrm{a}}$ & $0.27(0.05)^{\mathrm{a}}$ & $0.104(0.019)^{\mathrm{a}}$ \\
\hline & $\mathrm{C}$ & 9 & $25.9(0.8)^{\mathrm{a}}$ & $14.9(0.5)^{\mathrm{a}}$ & $1.52(0.11)^{\mathrm{a}}$ & $0.170(0.009)^{\mathrm{a}}$ & $0.356(0.014)^{\mathrm{a}}$ & $0.25(0.07)^{\mathrm{a}}$ & $0.055(0.022)^{\mathrm{a}}$ \\
\hline & $\mathrm{HE}$ & 9 & $26.8(0.8)^{\mathrm{a}}$ & $15.4(0.5)^{\mathrm{a}}$ & $1.59(0.11)^{\mathrm{a}}$ & $0.176(0.009)^{\mathrm{a}}$ & $0.375(0.013)^{\mathrm{a}}$ & $0.23(0.06)^{\mathrm{a}}$ & $0.066(0.021)^{\mathrm{a}}$ \\
\hline & HEP & 11 & $28.0(0.7)^{\mathrm{a}}$ & $16.3(0.4)^{\mathrm{a}}$ & $1.54(0.10)^{\mathrm{a}}$ & $0.178(0.008)^{\mathrm{a}}$ & $0.411(0.012)^{\mathrm{b}}$ & $0.27(0.05)^{\mathrm{a}}$ & $0.088(0.019)^{\mathrm{a}}$ \\
\hline \multirow[t]{4}{*}{$\mathrm{HG}$} & 5015 & 9 & $41.9(0.8)^{\mathrm{c}}$ & $24.5(0.5)^{\mathrm{b}}$ & $2.62(0.11)^{b}$ & $0.240(0.010)^{\mathrm{a}}$ & $0.465(0.013)^{\mathrm{a}}$ & $0.49(0.06)^{\mathrm{b}}$ & $0.190(0.021)^{\mathrm{a}}$ \\
\hline & $\mathrm{C}$ & 10 & $36.6(0.8)^{\mathrm{a}}$ & $22.1(0.5)^{\mathrm{a}}$ & $2.14(0.10)^{\mathrm{a}}$ & $0.212(0.009)^{\mathrm{b}}$ & $0.464(0.013)^{\mathrm{a}}$ & $0.27(0.06)^{\mathrm{a}}$ & $0.128(0.020)^{\mathrm{a}}$ \\
\hline & $\mathrm{HE}$ & 9 & $39.5(0.8)^{b}$ & $24.4(0.5)^{b}$ & $2.21(0.10)^{\mathrm{a}}$ & $0.236(0.009)^{\mathrm{a}}$ & $0.490(0.014)^{\mathrm{a}}$ & $0.51(0.06)^{b}$ & $0.191(0.021)^{\mathrm{a}}$ \\
\hline & HEP & 10 & $40.0(0.7)^{b}$ & $24.0(0.4)^{\mathrm{b}}$ & $2.24(0.10)^{\mathrm{a}}$ & $0.256(0.009)^{\mathrm{a}}$ & $0.496(0.013)^{\mathrm{a}}$ & $0.32(0.06)^{\mathrm{a}}$ & $0.183(0.020)^{\mathrm{a}}$ \\
\hline \multicolumn{10}{|c|}{ Probabilities } \\
\hline \multicolumn{3}{|l|}{ Diet } & $* * *$ & $* * *$ & $* *$ & $*$ & $* * *$ & NS & NS \\
\hline \multicolumn{3}{|l|}{ Line } & $* * *$ & $* * *$ & $* * *$ & $* * *$ & $* * *$ & $* * *$ & $* * *$ \\
\hline \multicolumn{3}{|c|}{ Diets within C57 } & NS & NS & NS & NS & $*$ & NS & NS \\
\hline \multicolumn{3}{|c|}{ Diets within $\mathrm{HG}$} & $* * *$ & $* *$ & $* *$ & $* *$ & NS & $* *$ & NS \\
\hline
\end{tabular}

Diet means within line sharing a common superscript $(\mathrm{a}, \mathrm{b}, \mathrm{c})$ are not significantly different. Line means within diet were significantly different $(P<0.05)$ for all traits, with the exception of gonadal fat in diets $C$ and HEP. Standard error is shown in parenthesis next to each mean value. Threshold values for probabilities are NS: $P>0.05, * P<0.05, * * P<0.01, * * * P<0.001$ 
had the most marked effect on HG females, and those mice on the $\mathrm{C}$ diet were the leanest of all. The gonadal fat pad was heavier in HG females fed diets 5015 and HE. However, no significant differences were detected between lines when gonadal fat weight was expressed as a percentage of body weight. A similar trend was observed for retroperitoneal fat; however, the small sample size and high variability within treatments precluded the detection of statistically significant differences. There was a negative correlation between the size of fat depots and litter size (data not shown): mice rearing larger litters were leaner at weaning.

\section{DISCUSSION}

Similar to growth traits [12], genotype $\times$ diet interactions involving C57 and congenic $\mathrm{HG}$ female mice were detected in the present experiment for reproductive traits.

In order to have a base of comparison for differences in intake among diets, feed intake was measured in the first week of the experiment and the first week of the mating period when three females were sharing a cage with one male. Feed intake was recorded again during lactation when nursing females were housed individually. Feed intake was not measured during the whole mating period because the females were at different stages of gestation and leaving the cage on different dates. Therefore, we were not able to estimate the cumulative feed intake during a complete reproductive cycle (from service to weaning). However, the intake of each diet was consistent across all stages of the experiment and conclusions can be drawn from these results.

From the four diets that were offered to the mice, higher intakes were recorded for diet 5015 which had the highest fat content with the lowest protein level (Tab. II). Although the other three diets had different compositions, much less variation in intake was detected among them. We estimated protein and energy intake for each line and diet by correcting feed intake by the protein and energy content of each diet (data not shown). This comparison suggested that keeping protein intake within certain limits could have been the factor limiting feed intake of each line, rather than energy content. For this reason, imbalances in the protein/energy ratio of each diet could have been the cause of differences in body composition detected in the weight of fat stores (Tab. V). Smith et al. [13] showed in a diet self-selection experiment that there is less variability in voluntary intake for protein than for either carbohydrates or fat among mouse inbred lines of similar body size. Unfortunately, source of macronutrients could have been a confounding factor influencing feed consumption. Casein was the source of protein for diets C, HE and HEP, whereas diet 5015 was formulated with soybean meal. In fact, reducing protein content and replacing casein by soybean as a source of protein has been recommended for long-term feeding of rodents in order to reduce the incidence of kidney lesions [15]. In the present experiment, a negative effect of a high protein diet was suggested by the fact that heavier kidneys were recorded for C57 mice fed the diet with $26 \%$ protein (HEP). This effect was not noticed in HG females probably due to higher protein requirements connected to their larger body size.

After the mating period, more HG than C57 females were removed from the experiment due to their low fertility, and even those that remained had more difficulty conceiving than the C57 females. Increasing protein content in the diet seemed to have a deleterious effect on the fertility of C57 females. This negative trend was not detected in HG females, probably because protein requirements were higher and/or because there were other limiting factors related to the HG phenotype.

Cargill et al. [11] identified some of the limiting factors that lead to the poor reproductive performance of HG females. Ovulation rate was similar to control mice, but litter size at birth was smaller, with HG losing more litters in late gestation or at birth. 
Although the estrous cycle was normal, the interval from mating to conception was longer in $\mathrm{HG}$, as found in the present experiment. From this evidence, it was concluded that luteal insufficiency was the most likely explanation for reproductive problems, rather than failures of ovulation, fertilization or early embryo development. A subsequent experiment involving reciprocal ovary transplantation [16] demonstrated that HG females failed to maintain pregnancy due to an insufficiency of the hypothalamus-pituitary axis, most likely involving the Prolactin (PRL) signaling pathway, given that mating-induced PRL surges are needed for maintenance of early gestation.

GH transgenics have an increase in body size comparable to that of $\mathrm{HG}$ mice and coincidentally, also manifest poor reproductive performance [17]. It has been proposed that one of the reasons for reproductive failure in $\mathrm{GH}$ transgenics could be an increased allocation of resources to growth to the detriment of reproduction, rather than to a dysfunction of the hypothalamus-pituitary axis [4]. Similar to GH transgenics, HG mice grow faster and have a higher feed intake, but feed conversion efficiency is higher [18]. The high levels of IGF-1 that are characteristic of HG could have the same effects as $\mathrm{GH}$ on nutrient partitioning. High-energy diets (up to $15 \%$ fat) partially overcome reproductive failure in GH transgenics [5]. However, in this case diets with up to $11 \%$ fat failed to overcome the reproductive impairment of HG. Although energy requirements of $\mathrm{HG}$ females could have been higher, these animals did not manifest a trend in the response of reproduction to energy intake. Also, mice from both lines managed to store energy as fat in a similar proportion when fed diet 5015 (Tab. V).

The explanation for the reproductive inefficiency of HG may reside in features of $h g$ other than the change in body size and nutrient requirements. In female rodents, PRL is essential for the maintenance of the corpus luteum and the expression of mating and maternal behaviors [19]. In contrast, male fertility does not seem to be affected by PRL deficiency [20]. Both GH and PRL can induce expression of members of the Socs gene family through the JAK-STAT pathway, which in turn downregulate the same pathway in a negative feedback loop [20, 21].

The role of SOCS-2 in the negative feedback signal regulating the GH/IGF-I axis is supported by the fact that SOCS $-2^{-1-}$ mice are $30-40 \%$ larger than normal mice [9]. This phenotype resembles that of Gh and Igf-I transgenics as well as HG mice. In the case of the PRL signaling pathway, SOCS-2 seems to have a role that distinguishes it from other members of the SOCS family. While SOCS- 1 and SOCS- 3 turn off the PRL signal, SOCS-2 seems to restore the sensitivity to PRL by interacting with the PRL receptor and suppressing the inhibitory effect of SOCS-1[22, 23]. Therefore, a link could exist between the lack of SOCS-2 in HG and reproductive failure associated with PRL, as proposed by Cargill et al. [16].

Differences in the number of pups weaned among line-diet combinations were very small; therefore they were not an explanation for the differences in weaning weight of the pups [24] (Tab. IV). Lactation poses a high-energy demand on females [25] and the inadequacy of diet $\mathrm{C}$ to cover energetic requirements of $\mathrm{HG}$ animals was also evidenced in weaning weight. Except in the $\mathrm{C}$ diet, HG pups were $22 \%$ heavier than C57, suggesting that the lower energy content of this diet was not compensated for by a higher feed intake. For the same reason, mice on diet $\mathrm{C}$ also weaned the lightest pups when compared across diets. As discussed above, the superiority in weaning weight of mice on diet 5015 can be attributed to the marked difference in intake during lactation compared to the rest of the diets and probably to a more favorable protein/energy ratio.

In summary, we demonstrate that C57 and HG female mice have a differential response to changes in diet composition in terms of reproduction and body weight and composition. Changes in diet composition failed to overcome reproductive problems 
in HG females. This failure is most likely associated with the physiological role of SOCS-2, independent of the effects of increased body size on reproduction per se.

\section{ACKNOWLEDGEMENTS}

We thank Charles Farber for his review of the manuscript. This research was supported by the University of California Davis Experimental Station.

\section{REFERENCES}

[1] Falconer DS, Mackay TFC. Introduction to quantitative genetics. 4th ed, Longman, Essex, 1996.

[2] Brien F. A review of the genetic and physiological relationships between growth and reproduction in mammals. Anim Breed Abst 1986, 54: 975-997.

[3] Turner ND, Knapp JR, Byers FM, Kopchick JJ. Expression of mutant bovine growth hormone genes in mice perturbs age-related nutrient utilization patterns. J Nutr 1998, 128: 520 524.

[4] Rollo CD, Kajiura LJ, Wylie D, D'souza S. The growth hormone axis, feeding and central allocative regulation: lessons from giant transgenic growth hormone mice. Can. J. Zool. 1999, 77: 1861-1873.

[5] Murray JD, Pomp D. Interaction between reproductive performance and dietary energy levels fed to female oMt1a-oGH transgenic mice. Transgenics 1995, 1: 553-563.

[6] Bradford GE, Famula TR. Evidence for a major gene for rapid postweaning growth in mice. Genet Res 1984, 44: 293-308.

[7] Wong M, Islas-Trejo A, Medrano J. Structural characterization of the mouse high growth deletion and discovery of a novel fusion transcript between suppressor of cytokine signaling-2 (Socs-2) and viral encoded semaphorin receptor (Plexin C1). Gene 2002, 299: 153-163.

[8] Horvat S, Medrano JF. Lack of Socs 2 expression causes the high growth phenotype in mice. Genomics 2001, 72: 209-212.

[9] Metcalf D, Greenhalgh C, Viney E, Willson T, Starr R, Nicola N, Hilton D, Alexander W. Gigantism in mice lacking suppressor of cytokine signalling-2. Nature 2000, 405: 1069-1073.

[10] Medrano JF, Pomp D, Sharrow L, Bradford GE, Downs TR, Frohman LA. Growth hormone and insulin-like growth factor-I measurements in high growth (hg) mice. Genet Res 1991, 58: 67-74.

[11] Cargill SL, Medrano JF, Famula TR, Anderson GB. Effects of the high growth $(h g)$ mutation on reproduction in High Growth (HG) female mice. Growth Dev Aging 1999, 64: 21-31.

[12] Corva PM, Medrano JF. Diet effects on growth and body composition in high growth $(\mathrm{hg} / \mathrm{hg})$ mice. Physiol Genomics 2000, 3: 17-23.

[13] Smith B, Andrews P, West D. Macronutrient diet selection in thirteen mouse strains. Am J Physiol Regul Integr Comp Physiol 2000, 278: R797-R805.

[14] SAS. OnlineDoc (TM), 7-1 edition. Cary, NC: SAS Institute Inc, 1998.

[15] McDonald R. Some considerations for the development of diets for mature rodents used in long-term investigations. J Nutr 1997, 127: 847S-850S.

[16] Cargill SL, Medrano JF, Anderson GB. Infertility in a line of mice with the high growth mutation is due to luteal insufficiency resulting from disruption at the Hypothalamic-Pituitary axis. Biol Reprod 1999, 61: 283-287.

[17] Bartke A, Chandrashekar V, Turyn D, Steger RW, Debeljuk L, Winters TA, Mattison JA, Danilovich NA, Croson W, Wernsing DR, Kopchick JJ. Effects of Growth Hormone Overexpression and Growth Hormone Resistance on neuroendocrine and reproductive functions in transgenic and knock-out mice. Proc Soc Exp Biol Med 1999, 222: 113-123.

[18] Calvert CC, Famula TR, Bernier JF, Khalaf N, Bradford GE. Efficiency of growth in mice with a major gene for rapid postweaning gain. J Anim Sci 1986, 62: 77-85.

[19] Freeman ME, Kanyicska B, Lerant A, Nagy G. Prolactin: Structure, function, and regulation of secretion. Physiol Rev 2000, 80: 1523-1631.

[20] Goffin V, Binart N, Touraine P, Kelly P. Prolactin: the new biology of an old hormone. Annu Rev Physiol 2002, 64: 47-67.

[21] Harrington J, Carter-Su C. Signaling pathways activated by the growth hormone receptor. Trends Endocrinol. Metabol. 2001, 12: 252-257.

[22] Dif F, Saunier E, Demeneix B, Kelly PA, Edery M. Cytokine-inducible SH2-containing protein suppresses PRL signaling by binding the PRL receptor. Endocrinology 2001, 142: 5286-5293.

[23] Pezet A, Favre H, Kelly P, Edery M. Inhibition and restoration of prolactin signal transduction by suppressors of cytokine signaling. J Biol Chem 1999, 274: 24497-24502.

[24] Speakman JR, Gidney A, Bett J, Mitchell IP, Johnson MS. Limits to sustained energy intake: IV. Effect of variation in food quality on lactating mice Mus Musculus. J Exp Biol 2001, 204: 1957-1965.

[25] Johnson M, Thompson S, Speakman J. Limits to sustained energy intake. I. Lactation in the laboratory mouse Mus musculus. J Exp Biol 2001, 204: 1925-1935. 